\title{
Walking Softly in
} Afghanistan: the Future of

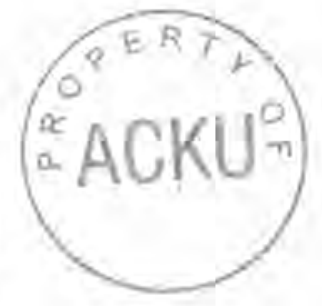

UN State-
Simon Chesterman

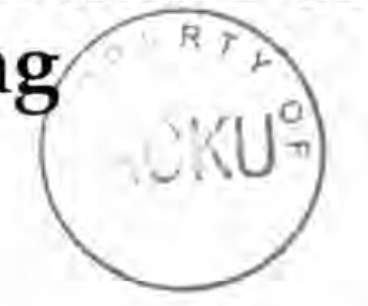

During the initial stages of the military action in Afghanistan, there was considerable discussion about the role that the United Nations would play after the war. Some feared that the UN would be handed a poisoned chalice once the United States had completed its military objectives; others eagerly looked forward to the 'next big mission' and a dominant role for the UN in rebuilding Afghanistan on the model of Kosovo and East Timor. ${ }^{1}$ These expectations were tempered by the challenging security environment and the decision by major states contributing forces to the International Security Assistance Force (ISAF) to limit their presence to the capital city of Kabul and its immediate vicinity. ${ }^{2}$ (Ongoing coalition actions in the east of the country continue to provide additional coercive power - referred to as the 'B- 52 factor' - but this is largely outside the control of the UN). Expectations were also limited by the political context within which the UN was to operate: however dysfunctional, Afghanistan had been and remained a state with undisputed sovereignty. This was quite different from the ambiguous status of Kosovo and the embryonic sovereignty of East Timor.

Under the leadership of Lakhdar Brahimi, the architect of the Bonn process, the UN mission adopted the guiding principle that it should first and foremost bolster Afghan capacity - both official and non-governmental - and rely on as limited an international presence and on as many Afghan staff as possible. This has come to be referred to as the 'light footprint' approach. ${ }^{3}$ Such a departure from the expansive mandates in Kosovo and East Timor substantially reduced the formal political role of the United Nations Assistance Mission in Afghanistan (UNAMA). This was in keeping with the limited role accorded to the United Nations in the Bonn Agreement, negotiated in December 2001 after the rout of the Taliban by the United States and its foreign and local allies, but also represents a philosophical challenge to the increasing aggregation of sovereign powers exercised in UN peace operations since the mid-19gos. ${ }^{4}$

Simon Chesterman is a Senior Associate at the International Peace Academy, where he directs the project on Transitional Administrations. He is the author of Just War or Just Peace? Humanitarian Intervention and International Law (Oxford University Press, 2001) and the editor of Civilians in War (Lynne Rienner, 2001).

Survival, vol. 44, no. 3, Autumn 2002, pp. 37-46 (c) The International Institute for Strategic Studies 


\section{Simon Chesterman}

\section{Politics and the light footprint}

Afghanistan represents a radically different model in the panoply of UN peace operations. On paper it resembles earlier assistance missions that provided governance and development support to post-conflict societies. In practice, however, it remains intimately involved with the Afghan Transitional Administration and therefore with the peace process that put it in place. This disjunction between formal authority and practical influence increases the risk that the political consensus established in Bonn will spin out of the control of the Transitional Administration and its UN partner.

Senior UN staff in the mission are blunt about the reasons for the light footprint approach. A mission on the scale of East Timor's transitional administration was 'not necessary and not possible', according to Lakhdar Brahimi. ${ }^{5}$ Bolstering Afghanistan's capacity to govern itself requires Afghans taking charge of their situation wherever possible - an end that may be compromised by throwing international staff at a problem. A large international presence may also have perverse effects on both politics and the economy. As another senior UN official put it, 'we are protecting a peace process from the hubris of the international liberal agenda as promoted by donors'. ${ }^{6}$ Such an agenda might include setting policy (on, say, human rights, democracy, gender, rule of law) in accordance with donor requirements and time-lines, rather than on the basis of what is locally feasible. Creating space for Afghans to establish their own political trajectory has extended not merely to reducing the number of staff that take up positions in Afghanistan, but to the length of time they are likely to be there. Unusually for the United Nations, at least some staff appear to be taking to heart the philosophy of the better development non-governmental organisations (NGOs) - that its main job is to work itself out of a job.

In any case, armchair commentators' enthusiasm for the benevolent takeover of Afghanistan was cooled by its history of resistance to foreign rule. The British and the Russians tried it before and failed; the UN knows that it runs the risk of being seen as simply the latest invasion force. For this reason, the Security Council-mandated ISAF has been reluctant to deploy outside its original sphere of operations in and around Kabul. The UN sees expansion beyond Kabul as essential to the stability of the Transitional Administration put in place by the Emergency Loya Jirga, but has been careful to limit itself to 'endorsing' Chairman Hamid Karzai's call for a wider deployment. The United States has been customarily reluctant to submit itself to a UN mandate, but has actively opposed any expansion of ISAF - despite the fact that it plays no formal part in the force. This may change once mopping up operations in search of al-Qaeda operatives and evidence of Osama bin Laden have been completed, leaving only the reluctance of those countries that would actually supply the troops.

Most importantly, however, a limited role for the UN was what was politically feasible at the time of the Bonn Agreement. One should be careful about taking the passive role of the UN at face value, of course - the 'procedural' decision to invite Hamid Karzai to speak at the Bonn meeting was not unconnected with his eventual appointment as Chairman of the Interim (and

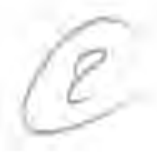


now Transitional) Administration. But a central element of the peace in Afghanistan established in Bonn has been encouraging Afghan leaders of various stripes to see their interests as being served by buying into a political process. Asserting a lead role for the UN, it is argued, would have fatally undermined this aim.

The accepted wisdom within the UN community is that a successful UN peace operation should, ideally, consist of three sequential stages. First, the political basis for peace must be determined. Then a suitable mandate for a UN mission should be formulated. Finally, that mission should be given all the resources necessary to complete the mandate. 7 The accepted reality is that this usually happens in the reverse order: states determine what resources they are prepared to commit to a problem and a mandate is cobbled together around those resources - often in the hope that a political solution will be forthcoming at some later date. A more scientific survey was conducted by Michael Doyle, now a Special Adviser in the Executive Office of the UN Secretary-General, and Nicholas Sambanis, who (uncontroversially) concluded that more hostile, complex and impoverished post-conflict situations will generally require greater international assistance and effective authority for a sustainable peace. ${ }^{8}$

On either measure, the UN mission in Afghanistan is doomed to failure. The Bonn Agreement put in place a process but the political basis for peace is still uncertain. The limited resources at the UN's disposal constrained its mandate and restricted its field presence largely to Kabul. By concentrating those limited resources in the capital, the UN made a bet that Hamid Karzai and the Interim Administration could hold the country together - even though the Interim Administration was less of a centralised government than it was a centralised gathering of factions, dominated by those favoured by the United States in its recent battle with al-Qaeda and the Taliban.

This hands-off approach has now become central to the political strategy currently being pursued by the UN - a high-risk strategy that requires two conceptual leaps from the normal mould of peace operations. The first is that it is possible to blur the normal divide between negotiating a peace agreement ('peace-making' in the UN argot) and implementing it. Thus the Bonn Agreement should be seen not as a final status agreement but as a framework for further negotiations, mediated through the institutions that it provides for over the subsequent two-and-a-half year period (the Interim Administration, the Emergency Loya Jirga, the Transitional Administration, the Constitutional Loya Jirga and so on). The flexibility inherent in this approach may be contrasted with the peace agreements that have locked the UN and other international actors into their roles in Bosnia and Kosovo. (The Dayton Accords in particular have become a de facto constitution for Bosnia. ${ }^{9}$ They served their purpose as a peace agreement but are utterly unworkable as a constitution - any attempt to change them, however, is seen as a threat to re-ignite the conflict.) The Bonn Agreement avoids these pitfalls, but presumes that the UN can continue to have a meaningful role in the ongoing negotiations. Again, on paper, there is little formal authority for the UN to do so, but through high-level diplomacy and 


\section{Simon Chesterman}

subtle interventions in its capacity as an assistance mission, it is endeavouring to 'cook' the political process into a sustainable outcome.

This assumes the success of the second conceptual leap, which is that the UN can make up for its small mandate and limited resources through exercising greater than normal political influence. Brahimi goes one step further, arguing that it is precisely through recognising Afghan leadership that one obtains credit and influence. ${ }^{10}$ Such an approach places extraordinary importance on the personalities involved. It is generally recognised that Brahimi was instrumental to the success of Bonn, but his continuing involvement and his personal relationship with Karzai and the three Panjshiri 'musketeers' who largely wield power (Foreign Affairs Minister Abdullah Abdullah, Defence Minister and Vice-President Muhammad Qassem Fahim and Education Minister and Special Adviser Mohammed Yunus Qanooni) are essential to the process remaining on track.

And, until the Emergency Loya Jirga, things were always likely to remain on track. Indeed, the greatest measure of the success of the operation to date is that no major group opted out of the Loya Jirga process entirely. There were cases of intimidation and pressure on the part of local commanders to have themselves or their men 'elected', but this is sanguinely interpreted as a compliment to the perceived importance of the political process. Few people deluded themselves into thinking that the Loya Jirga was a meaningful popular consultation - the aim was to encourage those who wield power in Afghanistan to exercise it through politics rather than through the barrel of a gun. Mao Zedong's aphorism is apposite here because the most dangerous period for the UN will come now that the Loya Jirga has taken place. At that point, if politics are not seen to deliver at least some of the benefits that were promised, those commanders may revert to more traditional methods of promoting their interests.

The Loya Jirga did produce a somewhat more representative government than that created by US bombs and UN diplomacy in December 2001. The question now is whether tinkering with a few positions is enough to assuage the disgruntled Pashtun population that sees itself as marginalised for the past sins of the Taliban. The difficulty confronting the UN is that it is neither mandated nor in a position to conduct meaningful consultations outside the power centre of Kabul. This is why many UN staff continue to see expansion of ISAF beyond Kabul as essential to the success of the larger mission. Any expansion now is highly unlikely. If it was going to happen, it should have been done while all parties were buying-in to the Loya Jirga process. Once in place, ISAF could have acted as a political guarantor in the areas outside Kabul that have thus far seen little evidence of the UN's presence. This would only be possible with US acquiescence, however - and it would only be likely if the US agreed to provide 'over the horizon' support in the event of a major conflict. Given the various other distractions in the world at present, however, even sustained US attention on Afghanistan beyond its military objectives seems unlikely. 


\section{Development and Afghan 'ownership'}

If the 'light footprint' approach has complicated the high-level diplomacy of UNAMA's political pillar, it has turned the development components of the UN mission on their head. During the anarchic Taliban period, humanitarian and development agencies frequently ran their programmes in Afghanistan without any formal relations with the government (with the notable exception of the health sector). In the absence of government capacity, the UN sometimes functioned as a surrogate ministry of planning. Now, with a recognised Afghan administration and a UN commitment to respect its authority, agencies and NGOs have had to undergo a mental revolution.

Every UN mission or development programme now stresses the importance of local 'ownership': 'Afghan solutions for Afghan problems' was a mantra of the preparations for Afghanistan's reconstruction. But this may be the first such mission where some of the local population themselves are truly taking charge. In part this unusual dynamic is the result of one man. Ashraf Ghani, formerly employed at the senior levels of the World Bank, has returned to Afghanistan and now heads an organisation called the Afghan Assistance Coordination Authority (AACA). Chaired by Hamid Karzai, AACA functions like a cabinet office on development issues. (Some archly suggest that Ghani himself functions more like a prime minister, noting that in addition to directing AACA he also serves as National Security Advisor.) This combination of experience and relative legitimacy has ruffled feathers, particularly when the AACA has refused to let development agencies and non-governmental organisations unroll their pre-packaged programmes and lay them out over Afghanistan.

Ghani has stated in the most explicit terms that he is determined not to allow Afghanistan to become a beggar state, dependent on international aid. The draft National Development Framework issued by AACA at times reads like a manifesto to which many developing countries might subscribe: 'donor-funded investment projects, unless they are anchored in coherent programs of government, are not sustainable. Structural adjustment programs, unless they are translated into feasible projects, do not result in reform'. "Agencies and NGOs complain that their programmes are being held up at the whim of a single person. AACA responds that aid packages with recurrent expenditures must either fit into a national framework or they will undermine it. Together with the Interim Administration, AACA is producing a Development Budget that will guide donors and agencies.

This serves a political function also. The legitimacy of the Transitional Administration depends on being seen to deliver a peace dividend. Agencies are therefore being encouraged to do less of their own flag-waving (at least within Afghanistan) and present their projects as action taken in support of the Transitional Administration. As a senior UN development official describes it, 'we are supporting the creation of the appearance of authority in the hope that it leads to the creation of actual authority'.

There are limits to how far this can go. Development is notoriously supplyrather than demand-driven; donor countries are notorious for pledging one thing 


\section{Simon Chesterman}

and delivering another. (Current wisdom puts the amount delivered at an average of around $60 \%$ of that pledged). Agencies must therefore take this into account when constructing fictional budgetary targets that they know will not be met, making responsible financial planning still more difficult.

Compounding these problems is confusion in Afghanistan as to what projects are actually going to be funded and when. This is partly caused by the refusal of some of the largest donors to have their money pooled into a trust fund for the whole of Afghanistan. There are good and bad reasons for this. The good reasons concern the high overheads and at times glacial pace of the World Bank and the UN Development Programme. The bad reasons are that countries often want their names up in lights next to their pet programmes, sometimes administered by their own national NGOs. Everyone wants to send children back to school; no one wants to pay military salaries. The result is that many donors want to do their own feasibility studies - sometimes on the same sector, sometimes even using the same consultant. As in Kosovo, this leads to a proliferation of local NGOs (and, in Afghanistan, government agencies) spending more and more of their time working out how to get foreign money and keep donors happy than actually running their programmes. Karzai railed against this at an April 2002 donors conference, attacking criticism of Afghan bureaucracy when donor countries' procedures were similarly obtuse:

\footnotetext{
We will not remove our red-tapeism unless you remove yours ... Don't expect us to give you a report every month: we will give you a report when we like to give you a report. There are too many groups of donors, reconstruction groups, assistance groups. I don't know the names of all of them ${ }^{12}$
}

Other recipient states would have been quietly cheering him on.

A radical approach to dealing with this problem was proposed in early 2002 but did not lead anywhere. This was to retain a private consulting firm to set up a trust fund that would be drawn upon directly by the Interim Administration, overseen by a board that would include both Afghan and UN members. Such a mechanism might allay the concerns of donors at giving funds directly to the UN or the World Bank, while at the same time directing money where it is most needed and encouraging fiscal responsibility on the part of the new regime. Such a mechanism would only be possible where local partners are in a position to absorb the money, but this seemed to be the case in Afghanistan (as demonstrated by its relations with donors to date). It remains an interesting hypothesis.

More can be said about the capacity of Afghanistan to absorb the sudden influx of wealthy foreigners. Every significant UN mission creates a parasitic and unsustainable economy to serve the needs of the transient internationals. As in cities from Dili to Freetown, the rental market in Kabul has exploded, accompanied by dubious evictions of existing tenants to make way for more lucrative foreign occupants. This can be a benefit to the economy if, as sometimes happened in East Timor, families move into a back room and rent out the rest of the house while using some of the money to renovate their property. In Kabul, many houses are of questionable ownership, or are claimed 
by absentee landlords. Much foreign money that enters the country thus leaves almost as quickly, while occupants formerly in cheaper accommodation become homeless.

Disputes over the microeconomic impact of the UN presence have focused on the question of salaries. The average monthly salary of an Afghan civil servant working for the government is currently about $\$ 28$, a figure that rises to only about $\$ 40$ for some ministers, or $\$ 8$ o for a supreme court judge. An Afghan national doing the same work for the United Nations or an international NGO earns between 15 and 400 times that amount, according to salary scales established by the International Civil Services Commission (ICSC). In May 2002 this was increased. Such differences foster and deepen the parasitic bubble economy, with staff leaving government positions to take the short-term international jobs on offer-even if it means that a judge is working as a driver, or an electrical engineer as a guard. This causes predictable problems as staff are poached from one place to the next, with organisations losing their institutional memories and such local capacity as actually exists being distorted into servicing the needs of the internationals.

The problem is unfairly blamed on the UN alone, when it is the ICSC that independently establishes the pay-scales for national staff. A creature of the UN General Assembly, modification of its procedures requires the initiative of a member state. Nevertheless, moves to lower the pay of national staff are unlikely to prove popular in New York. The problem is exacerbated by the low and relatively flat pay-scales of the Afghan administration. Raising basic pay and increasing the differential on the basis of responsibility may help reduce the incentive to leave, but the government will never be able to compete with the UN and international NGOs. Innovative solutions have been mooted, such as a proactive policy to recruit UN staff from the Afghan diaspora, and establishing two-way secondments between UN agencies and the government. In the short term, basic respect for notice requirements in contracts would help minimize the disruption of sudden staff changes. This could be enforced through a code of conduct - if there were one in place. Ultimately, the problem will most likely solve itself. As the international presence peaks and begins to decline, the job and property balloon will burst.

The relative lightness of the international 'footprint' has encouraged Afghan ownership of the development process and placed at least some controls on the distortions caused by the arrival of hundreds (rather than thousands) of international civilian staff. Nevertheless, the political and economic sides of the mission intersect with some obvious uncertainty on the part of donors about the political process. It is noticeable that few major infrastructure projects have yet been funded. Rather, the focus to date has been on delivering relief supplies, sending children back to school, agricultural projects and the like. The assessment of some in the development community is that donors have been waiting to see what happens after the Emergency Loya Jirga before releasing larger funds - and in the short term focusing on projects less likely to be affected by the outbreak of renewed fighting. 


\section{Simon Chesterman}

\section{Will it work?}

It is, of course, too early to make serious predictions as to the likely outcome of the process currently underway in Afghanistan. Nightmare visions of the Pashtun population rising up in bloody mutiny against a Tajik-dominated administration and their foreign abettors would require the political process spinning utterly out of control. At present this seems unlikely. Ongoing spats between rival commanders are highly likely, though to date these have been relatively localised. The first major tests were the staging of the Emergency Loya Jirga and how the new Transitional Administration presents itself to the population. The Loya Jirga is properly regarded as a success, but the Transitional Administration has got off to an extremely bumpy start. (The assassination of Vice-President Haji Abdul Qadir on 6 July 2002 was destabilising both as a blow against the government, but especially because it removed the most prominent political leader with a political base among the Pashtuns). Nevertheless, if most of those who have bought into the process achieve some of their expectations, and the Administration and the UN are seen to be facilitating the flow of assistance to the Afghan population, the fragile consensus that Afghanistan enjoys today will continue.

It is ironic that this mission reached its most crucial test within weeks of the conclusion of the UN Transitional Administration in East Timor (UNTAET). UNTAET may come to represent the high-water mark of UN peace operations, where the UN exercised effective sovereignty over a territory for more than two years. UNAMA has a fraction of its staff and budget and operates in a country perhaps 25 times the population of East Timor. Brahimi hopes that people will look back at East Timor and question whether it was necessary to assert such powers. Any such evaluation may well be coloured by the fate of the UN operation in Afghanistan. 


\section{Acknowledgements}

Thanks to David M. Malone for comments on an earlier draft of this text, and to all those who agreed to be interviewed in New York and Kabul. Field research was funded by the Carnegie Corporation of New York; the views expressed are those of the author alone.

\section{Notes}

1. This enthusiasm was encouraged by the impending staff reductions in East Timor and Kosovo, as well as staff cuts in UNHCR.

2 See United Nations Security Council Resolution 1386 (2001) para. 1. The United States and France were particularly adamant that the force would not be expanded outside Kabul and its immediate surrounds.

3. See The Situation in Afghanistan and Its Implications for International Peace and Security (Report of the SecretaryGeneral), UN Doc A/56/875-S/2002/ 278 (18 March 2002), para. 98.

+ See, e.g., Richard Caplan, A New Trusteeship? The International Administration of War-torn Territories
Adelphi Paper 341, (Oxford: Oxford University Press for the IISS, 2002).

5 Interview with Lakhdar Brahimi, Kabul, 9 May 2002.

- Confidential interview, Kabul, May 2002.

8. See Report of the Panel on United Nations Peace Operations, UN Doc A/ 55/305-S/2000/809 (21 August 2000), available at www.un.org/peace/ reports/peace_operations/

* Michael W. Doyle and Nicholas Sambanis, 'International Peacebuilding: A Theoretical and Quantitative Analysis', 94 American Political Science Review (2000) 779-801.

* The Accords do, in fact, include a constitution in Annex 4; the reference here is to the peace agreement as a whole-especially the military aspects in Annex $1 \mathrm{~A}$.

10 Interview with Lakhdar Brahimi, Kabul, 9 May 2002.

1) National Development Framework (Draft for Consultation), (Afghan Assistance Coordination Authority, Kabul, April 2002), 6.

12 'Karzai Urges Donors to Fulfil Pledges', Financial Times, 11 April 2002.

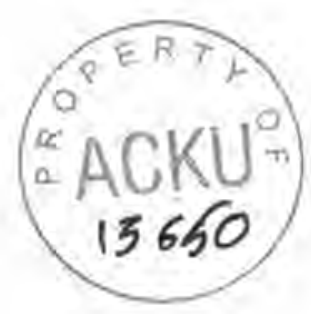

